\title{
Impacts of Organic Wastes on Water Quality of Woji Creek in Port Harcourt, Nigeria
}

\section{${ }^{1}$ DURU, CC; ${ }^{2 *}$ DANIEL, UI; ${ }^{3}$ OGBULIE, JN}

\author{
${ }^{\prime}$ Department of Biotechnology, School of Biological Sciences, Federal University of Technology, Owerri, Imo State, Nigeria. \\ ${ }^{2}$ Department of Animal and Environmental Biology, Faculty of Science, University of Port Harcourt, Choba, Port Harcourt, Nigeria. \\ ${ }^{3}$ Department of Microbiology, School of Biological Sciences, Federal University of Technology, Owerri, Imo State, Nigeria. \\ *Email: utibe.daniel@uniport.edu.ng, utibedaniel@yahoo.com
}

\begin{abstract}
The impacts of organic wastes contamination on water quality of Woji creek in Port Harcourt Rivers State were studied for two years. Surface water samples were collected monthly for the duration of two years at five sampling points using standard methods. The samples were subjected to physicochemical analyses based on temperature, $\mathrm{pH}$, turbidity, alkalinity, conductivity, total dissolved solid, total suspended solid, dissolved oxygen, BOD, COD, total organic carbon. Temperature range was found to be significantly higher in the dry season $\left(27.92 \pm 0.21^{\circ} \mathrm{C}\right)$ than in the wet season $\left(25.81 \pm 0.21^{\circ} \mathrm{C}\right)$. Conductivity measurement indicated significantly higher level in the dry season $(20596.20 \pm 1737.37 \mu \mathrm{s} / \mathrm{cm})$ than in the wet season $(9880.14 \pm 2878.49 \mu \mathrm{s} / \mathrm{cm})$. The findings of this study indicate that organic wastes are the major factors responsible for deterioration of the water quality of Woji creek.
\end{abstract}

\section{DOI: https://dx.doi.org/10.4314/jasem.v22i5.3}

Copyright: Copyright (C) 2018 Duru et al. This is an open access article distributed under the Creative Commons Attribution License (CCL), which permits unrestricted use, distribution, and reproduction in any medium, provided the original work is properly cited.

Dates: Received: 22 February 2018; Revised: 14 April: 2018; Accepted: 02 May 2018

Keywords: organic wastes, impacts, water, Physicochemical.

The benefits derived by man from natural surface waters are many. Apart from domestic uses, water is also necessary for many industrial activities. It provides means for transportation of raw materials and finished goods and also disposal of waste waters. Companies therefore tend to cluster on the banks of many rivers and adjoining creeks, especially in the urban cities. Urban migration in search of employment in these industrial areas contribute to the increase in waste generation. The continuous increase in population in the Cross River Coastal zone is attributable to the activities of the oil industry in the area; oil boom has led to a shift from farming to gainful employment. Most of the world's high population centers are found either in coastal marine areas or on river banks and this increasing coastal urbanization causes eutrophication of water. As the world population increases, more and more garbage are generated. Moreso, not all the garbage produced are properly disposed of. Some of them disrupt the environmental set up through the air, water or land. Raymond (1977) remarked that wastes can affect water, land, or air qualities if proper practices of management are not followed. Wastes can be valuable for crops but can cause water quality impairment. Wastes also contain organic solids, traces of heavy metal salts, bacteria, virus, other microorganisms and sediments. Domestic sewage and industrial waste water containing large quantities of chemical substances are drained into rivers without treatment causing serious water pollution.

In recent years aquatic pollution has become issue of great interest in Nigeria, especially in urban and semi urban cities. Many rivers in Nigeria are used for disposal of solid wastes and wastes water usually untreated causing water pollution. This practice has greatly altered the ecological balance of rivers in Nigeria. The problem of getting quality drinking water from surface water bodies is increasing as a result of this discharge into aquatic ecosystems. Most communities in Nigeria lack pipe borne water supply and therefore rely on local surface and shallow ground water even when they are contaminated. Although agricultural and municipal wastes contribute largely towards water pollution, industries also discharge liquid and solid wastes directly into water bodies; these wastes constitute problems for both surface and ground waters. Most people in developing countries are deprived of the right to good drinking water as almost all available drinking water is highly contaminated. Our sources of domestic water supply are not only polluted by sewage but also by toxic discharge and emission from industries. Providing adequate drinking water of acceptable quality is a basic necessity and should be of national and international concern (Reid et al., 2003). Water from the river constitute an important source of drinking

*Corresponding author*Email: utibe.daniel@uniport.edu.ng, utibedaniel@yahoo.com 
water because of lack of pipe-borne water supply, and its quality is currently threatened by a combination of over abstraction, introduction of chemicals such as nitrates, pesticides and heavy metals etc.

Organic wastes dump caused environmental stress in coastal waters and this resulted to low landing of some important fish. Organic wastes contain materials which originate from living organisms. There are many type of organic wastes normally found in municipal solid waste (food, paper, wood, sewage sludge and yard waste, etc). Industrial wastes include meat processing waste, brewery waste, paper mill fibres, agricultural waste, animal and human wastes. The Woji creek is subjected to organic pollution arising from municipal wastes such as animal and human wastes, wastes from abattoir, refuse dumps, sewage or septic waste, industrial effluents. The creek is exceptionally prone to human impacts because of the numerous anthropogenic activities that are carried out there, for instance fishing, boat construction, wielding, sand mining, dredging, mangrove cutting, engine boat transportation. Although the impact of organic pollutant has never been investigated, bioaccumulation and magnification will definitely have adverse effects on man and aquatic biodiversity, especially at the points of pollutant discharge. The objectives of this study therefore were to investigate the impact of organic wastes on the water quality based on the concentrations and seasonal variations of physicochemical parameters of the water body in Woji creek.

\section{MATERIALS AND METHODS}

Study Area: The study area is one of the several adjoining creeks of the Bonny River Estuary. It lies between longitude $7^{0} 3^{\prime} \mathrm{N}$ and $7^{0} 1{ }^{\prime} 3^{\prime}$ ' $\mathrm{N}$ and latitude 4'48' $E$ and 4'52' E of Port Harcourt. The creek has its head at Rumuodara and flows unidirectionally downstream through Rumuodara swamp and traverses Port Harcourt-Aba express road. The water remains fresh and flows downstream in one direction until it reaches Mini Okoro bridge at Rumuogba. It has a confluence with the refinery creek at Okujagu to form the main tributary which drains into the Bonny River. Along the shores of the creek are located the Port Harcourt industries, markets, the main abattoir house and Port Harcourt zoological garden.

Sampling procedures: Samples were collected at 5 sampling points of the Woji creek. The samples were subjected to physicochemical analysis. Samples were collected once a month in two season's i.e dry and rainy seasons for duration of two years. The dry season was between November and March, while the rainy season was between June and October. Surface samples were collected approximately $20 \mathrm{~cm}$ below the surface. The samples were put into sterilized plastic containers preserved in ice chest box before taking to the laboratory for further analysis. Samples for biochemical oxygen demand $\left(\mathrm{BOD}_{5}\right)$ and dissolved oxygen (DO) were collected in BOD glass bottles; care was taken to avoid bubbles being trapped before fixing the stopper and later taken to the laboratory for further analysis.

Physicochemical analysis: The $\mathrm{pH}$ of the water was determined in situ by immersing the indicator electrode of the $\mathrm{pH}$ meter, allowing for few minutes to let the reading settle and recording the final reading. Temperature was determined in situ by dipping the thermometer of $110^{\circ} \mathrm{C}$ calibration range into the water and the reading is taken after 5 minutes interval. Conductivity was determined using conductivity meter. Total suspended solids (TSS) and total dissolved solids (TDS) was determined using gravimetric method. Turbidity was determined photometrically using a turbidimeter. Alkalinity was determined using titrimetric method. Dissolved oxygen (DO) and Biochemical oxygen demand (BOD) was determined using modified Winkler method as described by Bartram and Balance (1996). Rapid oxidation method was used to determine chemical oxygen demand (COD) and organic carbon. Chloride was determined by Morhr's method.

\section{RESULTS AND DISCUSSION}

Concentrations of physicochemical parameters in Woji creek: Surface water temperature: The surface water temperature value ranged from $24^{\circ} \mathrm{C}$ to $30^{\circ} \mathrm{C}$ with a mean of $26.80 \pm 0.12$ during the study period (Table 1). The highest mean value $27.15 \pm 0.36^{\circ} \mathrm{C}$ was recorded in sampling point 5 while the lowest $26.04 \pm 0.17^{\circ} \mathrm{C}$ was recorded in sampling point 1 . The mean value was higher in the dry season $(27.92 \pm 0.11)$ than in the wet season $(25.81 \pm 0.21)$. However, there was a significant variation in water temperature (sig $\mathrm{t}=0.00)$ at $\mathrm{P}<0.05$. The temperature values ranged between 24 to $30^{\circ} \mathrm{C}$ during the study period these were within the ranges reported by (Chindah et al., 1999). Temperature of natural inland water in the tropics generally varied between $25^{\circ} \mathrm{C}$ and $35^{\circ} \mathrm{C}$. The temperature fluctuation in this study can be attributed to the changes in weather condition i.e. geology and climate change. The high water temperature values recorded in the dry season can be attributed to the heat from the sun which increased the surface water temperature. Statistical analysis showed significant difference between the dry and wet seasons temperature. 
$p H$ : The $\mathrm{pH}$ values ranged between 4.74 and 7.28 with a mean of $6.06 \pm 0.05$ was recorded during the experiment. The highest mean value $(6.16 \pm 0.11)$ was recorded in sampling point 4 and the lowest 6.01 \pm 0.09 was recorded in sampling point 5 . The mean value was higher in the dry season $(6.36 \pm 0.12)$ than in the wet season $(6.21 \pm 0.34)$ however there was no significant variation in the $\mathrm{pH}(\mathrm{sig} \mathrm{t}=0.228)$ at $\mathrm{P}<0.05$. The $\mathrm{pH}$ values ranged from 4.74 to 7.28 . The values alternated between acidity and alkalinity. The mean $\mathrm{pH}$ was noted to have slight variation between points and seasons (Table 2), variation in $\mathrm{pH}$ could be as a result of climate change or meteorological event this is in support with the works of Odokuma and Okpokwasili (1993). High value of $\mathrm{pH}$ was noted in the dry than in the wet season. The lower $\mathrm{pH}$ value in the wet season can be associated with the high fresh water emptying into the creek from the adjoining swamp forest streams during wet season. This implies that season has a significant role in the $\mathrm{pH}$ of the creek.

Alkalinity: Alkalinity values ranged from 2.4 to $17.60 \mathrm{mg} / \mathrm{l}$ with a mean value of $8.23 \pm 0.27 \mathrm{mg} / \mathrm{l}$ during the study period. There was variation across the sampling points. Sampling point 2 recorded the highest mean value $(9.02 \pm 0.68 \mathrm{mg} / \mathrm{l})$ of alkalinity and the lowest value $(7.63 \pm 0.44 \mathrm{mg} / \mathrm{l})$ recorded in the sampling point 5 . Mean value was higher in dry season than wet season. There was no significant seasonal variation in alkalinity ( $\operatorname{sig} \mathrm{t}=0.286)$ at $\mathrm{P}<0.05$. Alkalinity is the acid neutralizing capacity of water body. It is also a reflection of the carbonate content of the rock and soils of the water basin. Higher alkalinity water often has higher $\mathrm{pH}$ and contains elevated levels of dissolved solids. Such water is not suitable for use in boilers, food processing and municipal water systems. Water with high alkalinity is undesirable because of the associated excessive hardness or high concentrations of sodium salts. The reported alkalinity in this study is below the acceptable range for natural surface water. The high level of alkalinity in dry season might be due to the increased atmospheric activities around and inside the creek. This is in line with the report of Chindah and Braide (2001) who observed higher value in the dry season than in the wet season.

Turbidity: Turbidity values ranged from 0.4 to $2.48 \mathrm{mg} / \mathrm{l}$ with a mean value of $0.1 \pm 0.04 \mathrm{mg} / \mathrm{l}$ during the study period. The highest mean value $(0.6 \pm 0.57)$ was recorded in sampling point 2 and 4 while the lowest mean value

$(0.58 \pm 0.54)$ was recorded in sampling point 1 . There was a slight fluctuation across the sampling points. The mean value was higher in the dry season than wet season. There was no significant seasonal variation in turbidity (sig $\mathrm{t}=0.49$ ) at $\mathrm{P}<0.05$. Turbidity is caused by suspended and fine insoluble particles and colloidal impurities like clay, silt and algae. Boyd (1981) reported that turbidity in natural water seldom exceeds $20,000 \mathrm{mg} / \mathrm{l}$ and even muddy waters usually have less than $2000 \mathrm{mg} / \mathrm{l}$. The turbidity range in this study is between 0.04 and $2.48 \mathrm{NTU}$ which is below the range of 2NTU to 47NTU reported by Asonye et al., (2007) for the turbidity of Nigerian rivers, streams and waterways. Turbidity values were higher during the dry season than the rainy season this have to do more with nutrient load of the effluent and the kind of activities that go on at the abattoirs down to the river bodies.

Total Organic Carbon (TOC): Total organic carbon value ranged from 0.02 to $0.304 \mathrm{mg} / \mathrm{l}$ with a mean value of $0.048 \pm 0.017 \mathrm{mg} / \mathrm{l}$. There was a slight variation of TOC across the sampling points with the highest mean value of $0.033 \pm 0.013 \mathrm{mg} / 1$ at sampling point 1 and lowest mean value of $0.030 \pm 0.013 \mathrm{mg} / \mathrm{l}$ at sampling point 4 . The mean value was higher in the wet season than dry season (Table 3). However there was no significant seasonal variation in TOC (sig $\mathrm{t}=0.231)$ at $\mathrm{P}<0.05$. Total organic carbon contains the dissolved and particulate organic carbon. The recorded range of TOC concentration was below the 1 to $30 \mathrm{mh} / 1$ for natural water. Higher levels in water indicate pollution resulting from anthropogenic inputs. The higher run-off from the surrounding and increased discharge of domestic, municipal and industrial wastes might be attributed to the higher total organic carbon level in the wet season and this contradicts the work of Davies and Tawari (2010).

Dissolved Oxygen (DO): DO values in the study area ranged between 0.0 and $5.6 \mathrm{mg} / \mathrm{l}$ with a mean value of $2.25 \pm 0.15 \mathrm{mg} / \mathrm{l}$. There were slight variations across the sampling points. The highest mean value $(2.64 \pm 0.36 \mathrm{mg} / \mathrm{l})$ was recorded in sampling point 1 while the lowest mean value $(1.68 \pm 0.26 \mathrm{mg} / \mathrm{l})$ was recorded in sampling point 5 . Mean value was higher in the wet season $(2.76 \pm 0.62 \mathrm{mg} / \mathrm{l})$ than in the dry season $(1.92 \pm 0.25)$. There was no significant seasonal variation in $\mathrm{DO}$ at $\mathrm{P}<0.05$. The high mean values of dissolved oxygen (DO) recorded in the wet season agrees with the findings of Egborge (1971), who reported that dissolved oxygen is generally higher during the wet season in the tropics. At high temperature the solubility of oxygen decreases while at lower temperature dissolved oxygen increases. DO is a very important quality parameter and the recommended minimal value for domestic use and fish population maintenance is $5 \mathrm{mg} / \mathrm{l}$ (USEPA, 1986). DO in this study showed variation in season, with higher values in the rainy season than the dry season. 
Biochemical oxygen demand $\left(\mathrm{BOD}_{5}\right)$ : $\mathrm{BOD}_{5}$ values ranged between 6.40 and $180 \mathrm{mg} / \mathrm{l}$ with a mean value of $51.71 \pm 4.34 \mathrm{mg} / \mathrm{l}$. sampling point 5 recorded the highest mean value $(60.10 \pm 10.36 \mathrm{mg} / \mathrm{l})$ while the lowest mean value $(40.23 \pm 8.09 \mathrm{mg} / \mathrm{l})$ was recorded in sampling point 2. Values fluctuated across the sampling points. Mean value was higher in the dry season than in the wet season. There were no significant variation at $\mathrm{P}<0.05$.

The varied BOD concentration along the points might be attributed to the different organic wastes of varied quantities entering the creek. The higher BOD level in dry season could be the effect of higher temperature and putrefaction of substances deposited in the creek from the surrounding (Davies et al., 2008).

.Table 1: Mean range, standard deviation and error of physicochemical parameters of Woji Creek.

\begin{tabular}{|c|c|c|c|}
\hline Parameter & Minimum & Maximum & Mean \pm Standard Error \\
\hline Temperature ${ }^{0} \mathrm{C}$ & 24 & 30 & $26.80 \pm 0.12$ \\
\hline $\mathrm{pH}$ & 4.74 & 7.28 & $6.058 \pm 0.048$ \\
\hline Alkalinity $(\mathrm{mg} / \mathrm{l})$ & 2.40 & 17.60 & $8.228 \pm 0.266$ \\
\hline Turbidity (mg/l) & 0.040 & 2.48 & $0.606 \pm 0.040$ \\
\hline Conduct $(\mu \mathrm{s} / \mathrm{cm})$ & 362.0 & 34050.00 & $15726.925 \pm 788.088$ \\
\hline Total Hardness $(\mathrm{mg} / \mathrm{l})$ & 8.010 & 8008.00 & $639.99 \pm 148.90$ \\
\hline $\mathrm{DO}(\mathrm{mg} / \mathrm{l})$ & 0.00 & 5.60 & $2.252 \pm 0.145$ \\
\hline $\mathrm{BOD}_{5}(\mathrm{mg} / \mathrm{l})$ & 6.40 & 180.00 & $51.705 \pm 4.341$ \\
\hline $\mathrm{COD}(\mathrm{mg} / \mathrm{l})$ & 16.00 & 530.00 & $127.329 \pm 7.906$ \\
\hline TDS (mg/l) & 180.00 & 25950.00 & $9536.775 \pm 567.811$ \\
\hline $\mathrm{TSS}(\mathrm{mg} / \mathrm{l})$ & 40.00 & 20650.00 & $2166.583 \pm 287.268$ \\
\hline TOC (mg/l) & 0.002 & 0.304 & $0.048 \pm 0.017$ \\
\hline
\end{tabular}

Key: $\mathrm{SE}=$ Standard error of mean; DO= Dissolved Oxygen; BODs= Biological Oxygen demand; TDS $=$ Total Dissolved Solid; TSS $=$ Total Suspended Solid TOC $=$ Total Organic Carbon COND= Conductivity; EMP $=$ Temperature; $\mathrm{T} / \mathrm{HARD}=$ Total Hardness

Table 2: Spatial variation of physicochemical parameters in water (mean \pm standard error)

\begin{tabular}{llllll}
\hline Parameter & 1 & 2 & 3 & 4 & 5 \\
\hline Temp ${ }^{0} \mathrm{C}$ & $26.04 \pm 0.17$ & $26.79 \pm 0.18$ & $26.88 \pm 0.23$ & $27.13 \pm 0.34$ & $27.15 \pm 0.36$ \\
$\mathrm{pH}$ & $6.06 \pm 0.11$ & $6.05 \pm 0.12$ & $6.02 \pm 0.12$ & $6.16 \pm 0.11$ & $6.01 \pm 0.09$ \\
Alk $(\mathrm{mg} / \mathrm{l})$ & $7.98 \pm 0.46$ & $9.02 \pm 0.68$ & $8.22 \pm 0.61$ & $8.33 \pm 0.75$ & $7.63 \pm 0.44$ \\
Turb $(\mathrm{mg} / \mathrm{l})$ & $0.58 \pm 0.54$ & $0.62 \pm 0.57$ & $0.61 \pm 0.56$ & $0.62 \pm 0.58$ & $0.61 \pm 0.57$ \\
Conduct $(\mu \mathrm{s} / \mathrm{cm})$ & $14660.71 \pm 1652.07$ & $15104.63 \pm 1796.39$ & $14925.71 \pm 1528.11$ & $17227.00 \pm 2025.89$ & $16465.00 \pm 1935.96$ \\
Total Hardness $(\mathrm{mg} / \mathrm{l})$ & $617.79 \pm 299.56$ & $776.02 \pm 394.18$ & $637.47 \pm 291.25$ & $785.97 \pm 392.27$ & $652.68 \pm 297.30$ \\
DO $(\mathrm{mg} / \mathrm{l})$ & $2.64 \pm 0.36$ & $2.58 \pm 0.31$ & $2.36 \pm 0.33$ & $2.00 \pm 0.33$ & $1.68 \pm 0.26$ \\
BOD $(\mathrm{mg} / \mathrm{l})$ & $40.40 \pm 6.91$ & $40.23 \pm 8.09$ & $55.32 \pm 11.09$ & $56.57 \pm 10.42$ & $60.10 \pm 10.38$ \\
COD $(\mathrm{mg} / \mathrm{l})$ & $118.40 \pm 18.32$ & $108.91 \pm 12.62$ & $125.06 \pm 17.01$ & $145.29 \pm 23.25$ & $139.01 \pm 15.90$ \\
TDS $(\mathrm{mg} / \mathrm{l})$ & $9047.67 \pm 1141.16$ & $9843.67 \pm 1453.64$ & $9176.71 \pm 1158.37$ & $10335.00 \pm 1245.55$ & $9280.83 \pm 1406.39$ \\
TSS $(\mathrm{mg} / \mathrm{l})$ & $1647.50 \pm 261.02$ & $1432.71 \pm 179.46$ & $1536.38 \pm 200.62$ & $1753.75 \pm 209.65$ & $1698.00 \pm 191.09$ \\
TOC $(\mathrm{mg} / \mathrm{l})$ & $0.033 \pm 0.013$ & $0.031 \pm 0.013$ & $0.031 \pm 0.013$ & $0.030 \pm 0.013$ & $0.031 \pm 0.013$ \\
\hline
\end{tabular}

Table 3. Seasonal variation (students t-test; $\mathrm{p}<0.05$ ) of physicochemical parameters

\begin{tabular}{|c|c|c|c|c|c|c|}
\hline Parameter & Season & Mean \pm SE & $\mathrm{R}$ & Sig $\mathrm{r}$ & $\mathrm{T}$ & Sig $\mathrm{t}$ \\
\hline \multirow[t]{2}{*}{ TEMP } & Wet & $25.81 \pm 0.21$ & -0.047 & 0.898 & -8.891 & 0.000 \\
\hline & Dry & $27.92 \pm 0.11$ & & & & \\
\hline \multirow[t]{2}{*}{$\mathrm{pH}$} & Wet & $6.21 \pm 0.34$ & 0.563 & 0.090 & -0.530 & 0.609 \\
\hline & Dry & $6.36 \pm 0.12$ & & & & \\
\hline \multirow[t]{2}{*}{$\mathrm{ALK}(\mathrm{mg} / \mathrm{l})$} & Wet & $8.05 \pm 0.68$ & -0.241 & 0.503 & -1.134 & 0.286 \\
\hline & Dry & $9.06 \pm 0.44$ & & & & \\
\hline \multirow[t]{2}{*}{ TURB(mg/l) } & Wet & $0.55 \pm 0.03$ & -0.276 & 0.440 & -0.713 & 0.494 \\
\hline & Dry & $0.68 \pm 0.16$ & & & & \\
\hline \multirow[t]{2}{*}{$\mathrm{COND}(\mu \mathrm{s} / \mathrm{cm})$} & Wet & $9880.14 \pm 2878.49$ & 0.165 & 0.649 & -2.977 & 0.016 \\
\hline & Dry & $20596.20 \pm 1737.37$ & & & & \\
\hline \multirow[t]{2}{*}{ T/HARD(mg/l) } & Wet & $1224.80 \pm 731.71$ & -0.182 & 0.613 & 1.092 & 0.303 \\
\hline & Dry & $356.62 \pm 204.94$ & & & & \\
\hline \multirow[t]{2}{*}{$\mathrm{DO}(\mathrm{mg} / \mathrm{l})$} & Wet & $2.76 \pm 0.62$ & 0.714 & 0.631 & 1.339 & 0.214 \\
\hline & Dry & $1.92 \pm 0.25$ & & & & \\
\hline \multirow[t]{2}{*}{ BODs(mg/l) } & Wet & $44.07 \pm 12.98$ & 0.161 & 0.656 & -1.299 & 0.226 \\
\hline & Dry & $63.54 \pm 9.88$ & & & & \\
\hline \multirow[t]{2}{*}{$\mathrm{COD}(\mathrm{mg} / \mathrm{l})$} & Wet & $104.48 \pm 21.22$ & -0.069 & 0.850 & -2.107 & 0.064 \\
\hline & Dry & $159.42 \pm 13.76$ & & & & \\
\hline \multirow[t]{2}{*}{ TDS(mg/l) } & Wet & $7540.20 \pm 2302.65$ & -0.467 & 0.174 & -1.193 & 0.170 \\
\hline & Dry & $12398.80 \pm 1462.59$ & & & & \\
\hline \multirow[t]{2}{*}{$\mathrm{TSS}(\mathrm{mg} / \mathrm{l})$} & Wet & $2485.08 \pm 1376.57$ & -0.599 & 0.068 & 0.256 & 0.804 \\
\hline & Dry & $2082.80 \pm 298.93$ & & & & \\
\hline \multirow{2}{*}{$\mathrm{TOC}(\mathrm{mg} / \mathrm{l})$} & Wet & $0.06 \pm 0.031$ & -0.343 & 0.332 & 0.256 & 0.231 \\
\hline & Dry & $0.014 \pm 0.003$ & & & & \\
\hline
\end{tabular}

DURU, CC; DANIEL, UI; OGBULIE, JN 
Chemical oxygen demand (COD): COD values ranged between 16.0 and $530 \mathrm{mg} / \mathrm{l}$ with a mean of $127.33 \pm 7.91 \mathrm{mg} / \mathrm{l}$. The highest mean value was recorded in sampling point 4 while the lowest mean value was recorded in sampling point 2 . There was variation of values across the sampling points. Mean value $(159.42 \pm 13.76 \mathrm{mg} / \mathrm{l})$ was higher in the dry season than wet season (104.48 \pm 21.22$)$. There was no significant seasonal variation at $\mathrm{P}<0.05$. The chemical oxygen demand (COD) was higher in the dry season than in the rainy season. The reasons could still be attributed to increase in organic and inorganic waste load noted during the study. The COD increases as one proceeds downstream.

Conductivity: Electrical Conductivity values ranged from 362 to $3405 \mu \mathrm{s} / \mathrm{cm}$ with a mean value of $15726.93 \pm 471.76 \mu \mathrm{s} / \mathrm{cm}$. Sampling point 4 recorded the highest mean value and the least mean value was recorded in sampling point 1 . The mean value was higher in the dry season than the wet season. There was a significant seasonal variation in conductivity (sig $\mathrm{t}=0.016$ ) at $\mathrm{P}<0.05$. Conductivity is the ions capacity of water. Carbonate and other charged particles increase the conductivity of a water body. There was increase in conductivity at the end of the experiment, this agrees with the report of Eze (2005) that conductivity increases towards the downstream. Conductivity values were higher during the dry season than the rainy season; this could be attributed to the electrolytes being more concentrated in the dry season as a result of reduced water volume caused by evaporation.

Total Dissolved Solids (TDS): TDS values ranged between 180 and $25950 \mathrm{mg} / \mathrm{l}$ with an overall mean value of $9536.78 \pm 567.81 \mathrm{mg} / \mathrm{l}$. The highest mean value $(10335 \pm 1245.55 \mathrm{mg} / \mathrm{l})$ was recorded in sampling point 4 and the least mean value $(9047.67 \pm 1141.16 \mathrm{mg} / \mathrm{l})$ was recorded in sampling point 1 . Mean value was higher in the dry season than the wet season. However there was no seasonal variation in TDS at $\mathrm{P}<0.05$. The total dissolved solid is an index of the amount of dissolved substances from anthropogenic sources in the water body. The presence of such solutes alters the physical and chemical properties of water. The mean values for the total dissolved solids (TDS) were higher in the dry season than in the rainy season. The lower values of this parameter suggest that the run- off water only contributed to its dilution in the rainy season. This is in contrast with the results of Odokuma and Okpokwasili (1990).

Total Suspended Solids (TSS): TSS values ranged from 40 to $5200 \mathrm{mg} / \mathrm{l}$ with a mean value of $2166.58 \pm 287.27 \mathrm{mg} / \mathrm{l}$. However there was variation of values across the sampling points. At sampling point 4 TSS was highest $(1753.75 \pm 209.65 \mathrm{mg} / \mathrm{l})$ and lowest $(1432.71 \pm 179.46 \mathrm{mg} / \mathrm{l})$ at sampling point 2 . Mean value was higher in the wet season than dry season. There was significant seasonal variation in TSS at $\mathrm{P}<0.05$. Total suspended solid (TSS) refers to the filterable particles in water which may be of organic or inorganic source. Total suspended solids values obtained during the rainy season were higher than the values for dry season. This may be as a result of runoff flow of rain water from the slaughter house and the environment.

Total Hardness: Total Hardness values ranged between 8.01 and $8001 \mathrm{mg} / \mathrm{l}$ with a mean value of $683.99 \pm 148.90 \mathrm{mg} / \mathrm{l}$. The highest mean value was recorded at sampling point 4 while the lowest mean value was recorded at sampling point 1 . There was a wide fluctuation of values across the sampling points. Mean value was higher in the wet season than the dry season. There was no seasonal variation at $p<0.05$. The wet season values of total hardness were generally higher than the dry season values. The level of total hardness recorded was between 8.0 and 8008 . This exceeds the permissible limit of 100 to $250 \mathrm{mg} / \mathrm{l}$. Water with hardness above $200 \mathrm{mg} / \mathrm{l}$ may cause scale depletion in treatment works, excessive soap consumption and subsequent scum formation (WHO, 2004). This will also increase the use of water for domestic purposes.

Conclusion: The activities going on at the shores of the creek such as effluents discharge of abattoir wastes, human sewage and animal wastes discharge have been identified as major sources of pollutants in the creek and thereby creating a public health risk. The increasing values of other parameters of certain contaminants also indicate that the Woji Creek water will be unsafe for domestic purposes without some forms of physical and chemical treatments. Conclusively, this study shows that organic wastes are the major factors responsible for deterioration of water quality of Woji creek and therefore proper managements and preventive measures is hereby advocated to avoid an epidemic in the nearest future.

\section{REFERENCES}

Asonye, CC; Okolie, NP; Okenwa, EE; Iwuanyanwu, UG, (2007). Some physicochemical characteristics and heavy metals profile of Nigerian rivers, streams and water ways. Afr.J. Biotechnol., 6(5):617-624.

Bartram, J; Balance, R. (1996). Water Quality Monitoring, published on behalf of United 
Nations Environment Programme, World Health Organization. E and FN SPON. An imprint of chapman and Hall London $1^{\text {st }}$ edition.pp 90210 .

Boyd, CE (1981). Water quality in warm water fish pond $2^{\text {nd }}$ Ed., Alabama Craftmaster, 359 p.

Chindah, AC; Hart, AI; Uzoma, A. (1999). Periphyton associated with submerged macrophytes (Crinium nations) in the upper reaches of the New Calabar River, Niger Delta. Afri.J. Applied Zoology. 2:29-33.

Chindah, AC; Braide, SA. (2001). Crude oil spill and the phytoplankton community of a swamp forest stream. African Journal of Environmental Studies 2(1):1-8.

Davies, OA; Tawari, CC. (2010). Seasonal and tidal effects on sediment characteristics of TransOkpoka creek, upper Bonny Estuary, Nigeria. Agriculture and Biology Journal of North America. pp 92-93.

Davies, OA; Ugwumba, AAA; Abolunde, DS. (2008). Physico-chemistry quality of Trans-Amadi (Woji) creek, Port Harcourt, Niger Delta, Nigeria. J. Fish. Int. 3(3):91-97.

Egborge, ABM (1971). The chemical hydrology of River Osun, Western State, Nigeria. Journal. Of Fresh water Biol. 1:257-271.

Eze, VC (2005). Aspects of the Ecodynamics of a Niger Delta Rivers Receiving Industrial Effluents. Unpublished Ph.D. thesis Dept. of Microbiology, University of Port Harcourt.
Fouzia, I; Amir, K (2013). Effect of heavy metals on the water quality of River Tons and River Asian in Doon valley, Uttarakhand India. Global Journal of Biotechnology and Biochemistry $8(1): 8-14$.

Odukuma, LO; Okpokwasili, GC (1993). Season ecology of hydrocarbon utilizing microbes in the surface water of New Calabar River. Environmental Man. Assess 27(3):175-191.

Odukuma, LO; Okpokwasili, GC (1990). Seasonal influence on the organic pollution monitoring of the New Calabar River. Nig. Environ. Monitor Assess, 5:1-1.

Raymond, CI (1977). Pollution control for agriculture. New York academic press Inc. 13p.

Reid, DC; Edwards, AC; Cooper, D; Wilson, E; Mcgaw, BA (2003). The quality of drinking water from private supplies in Aberdeenshire, UK. Elsevier Science Ltd. UK. Wat. Res. 35:245-245.

USEPA (1986). US Environmental Protection Agency and Standards, Washington D.C. EDA 440/5-58081.

WHO (1984). Guidelines for drinking water quality. Vol. (1\&2) Geneva. Cited in summary evaluation of existing waste management systems in the four most industrialized states (Kano, Kaduna, Rivers, Lagos) 22p

WHO (2004). Guidelines for drinking water quality. $3^{\text {rd }}$ ed. Vol.1 Recommendations. Pp210-220. 